\title{
COVID-19 Forced Social Distancing and Isolation: A Multi-Perspective Experience
}

\author{
Bruce Janz \\ (University of Central Florida; Orlando; bruce.janz@ucf.edu) \\ ORCID: 0000-0003-3122-1618 \\ Eka Kaznina \\ (Pedagogical University of Sankt Petersburg; ekaznina@gmail.com)
}

\section{Kim Jihyun}

(Jeju National University; Jeju; 99zini@gmail.com)

\section{Claudia Ammann}

(Dunedin/Otago; claudia.g.ammann@gmail.com)

ORCID: 0000-0002-4717-8573

David Kohlberg

(Kohlberg Educational and Publishing Foundation; Bodghaya/Bihar; davidkepf@gmail.com)

\section{Cătălin Mamali}

(independent scholar; Iowa; catalin.mamali@loras.edu)

\author{
Only man, as opposed to nature, has the faculty of \\ binding and unbinding, \\ and in this specific manner: that one is always the \\ presupposition of the other. \\ Georg Simmel, „Bridge and door”
}

\section{Walking, Solitude, and Viruses (by Bruce B. Janz)}

I walk a lot, in this strange and solitary time. In August, I walked over 300 miles (490 km). Most months I walk the equivalent of at least ten marathons. It's always alone, no headphones, long before dawn, on recreational trails that stretch along old railway beds. Most days, these walks are between 2.5-3 hours in length. Most days, they run along the same or very similar routes. 
I started walking these distances before COVID-19 changed everything we knew and experienced of the world, but the walking took on new meaning once everyone started isolating. I have the luxury of being able to do my job from home, via computer, and so the stress of joblessness is not an imminent threat.

This should be a natural experiment. You know, the kind that would never pass an institutional review board for ethical treatment of subjects, but which is happening anyway. Knowing that in the absence of having to drive to work (well, in the absence of being able to tell a Monday from a Saturday in this new isolated reality), I started my own informal experiments on the trail. Enactivist cognitive science has emphasized our interrelatedness, the fact that we are bodies in the world, extended into our technology, our organizations, our architecture, enactively related to the world (in other words, we do not simply think first and on the basis of that thinking act, but the arrow goes both directions - in acting we also think).

Solitude, then, should be a form of damage to our cognition, if enactivism is right. And often it is. One of the worst punishments we can imagine is solitary confinement. And yet, people also seek solitude as a way of focusing the mind, or even achieving transcendence. We are interconnected, without question, and that is a fundamental cognitive feature of being human. And so, after the initial shock of enforced separation, isolation, and solitude, the question is, how do we find ways of drawing on the connections already written into our environments, and the habits we still have some control over, in order to make solitude less like confinement and more like exploration?

That was my task, on my walks. At this writing I have walked since the beginning of January, every day. 261 days in a row and counting. The sameness of the route could lead to boredom, but I try to learn from the devotion of religious figures from many traditions. The task: to use the repetition, monotony even, to break past boredom to something else. I look at stars, and clouds, and leaves and water, and think about the subtle variations from one day to the next. I try to deconstruct the debts I owe to my culture and that of others in how I look at the world, and try to hold those habits in abeyance at least some times. I look for textures and flows and patterns, not just objects.

And I take pictures and write, and post these things to Facebook and to a blog. The point has been not to just inflict the minutiae of my world on those who follow my page. The point has been to implicitly ask, what practices of secular devotion or attention can we engage in, to leverage our embodied, embedded, extended, enactive presence in the world into a positive narrative about this time of isolation?

I say much of this better in some of the posts, so here are a few. There were many more than this - it was almost a diary, kept in public on Facebook. Most of these posts started with "Your morning X" - Your morning sunrise, your morning pond, your morning alligators - and they came with video or images. The visual content is not possible in this format, but the text is. Some that were not included are very much dependent on seeing video or images, and they tend to the be ones with the closest observations. What 
is included here is phenomenological, but at the level of the social world, for the most part. Solitude, after all, means something, it is not just the lack or the absence of previous meaning, and so understanding what that is under these circumstances, living in a country which is arguably the worst in the world at containing the spread of the virus, is what I am trying to do.

\section{April 4}

I tell my students that the spaces they move through are texts, or at least are textualizable, that is, they can be made into texts (maybe they can be made into other things too, but at least texts).

So I'm aware of the textuality of space as I move through it during the pandemic. I'm aware of all the instructions about social/physical distancing and isolation. What strikes me, though, is the confusing and contradictory text in social space right now.

Examples: I'm out on the trail, early in the morning, running or walking, depending on my mood. It might suggest something too rustic to call it a trail - it's mostly a paved path, about 8 feet or so wide. If we're taking the 6 foot rule seriously, plenty of room to move.

Of course, there are plenty of people out there who just don't seem to care about that rule. They come much closer when passing. Bikers in particular seem to think that it doesn't apply to them. They can fly past within a foot or so.

But the obvious rulebreakers aren't the ones who interest me. What's interesting is that in social space, we need to both observe these rules, but also be seen to be doing so, and also communicate with others, even passively, that the path is a safe space.

My solution to this? As far as I can tell, it is a unique solution, in that I have yet to see anyone else doing it. I often walk in the ditch or on the grass beside the path. This isn't a claim of moral superiority on my part; what I'm interested in is space as a text that we are all reading. I want others to read me as saying that they are safe with me around. As far as I know, I don't have the virus - no symptoms, have been isolated for a long time now. But they don't know that, and I don't know them. And so, in that absence of knowledge, I need to try to communicate something.

There are other ways. Lots of people are nodding, waving, trying to be friendly. That's great. Sometimes it is sincere, sometimes I suspect it's something else, more like "hey bro, we're out here together because we know this whole virus panic thing is overblown and clearly you get it like I do." Yeah, no, that's not how I want to be read, but there's always a hermeneutic of suspicion going on, that is, a way of reading that isn't about what I'm trying to communicate, but instead what I'm communicating despite my best efforts to hide it. I think I'm being virtuous, maybe I'm just another don't-give-a-fuck guy who's living my own life, who cares what the guvmint says. Well, I hope I'm not being read like that, but I can't really help it if I am.

I'm out there to read something other than my fellow humans. There's a reason I go 
out early in the morning. It's before most of the cars, and most of the people. What I want to read is the bird activity, and other animals. I want to "read" the "olfactory poems" that Aldo Leopold talked about when he observed his dog out on a walk early in the morning with him, following invisible paths and barking at completely unseen and mysterious things. The text was different for his dog, but no less real. I want some of those texts, in a time of control, in a time when we are trying to flatten curves and pull this weird viral perturbation in our systems back into proper orbit.

And so, my walks have a narrative, a kind of trajectory. I start in the dark, with these little lights on my shoes that cast elongated shadows on the path, and send little creatures scurrying. About 45 minutes in, daybreak happens, and the birds kick into high gear. Still very few out at this point - some bikes, moving fast, and a few regulars who I'm trying to get to know by name (by introducing myself, no hand-shaking of course). The sun comes up as I go past ponds and lakes, and the shorebirds are wading around, and the occasional gator makes an appearance. And the olfactory poems are there too, although I'd need a dog to really understand those.

By the time the sun's up, others are out, and I'm back in the mode of textualizing myself for others, walking in ditches. Some of them think I'm weird, I'm sure. No matter. I can't control their reading of me, but I hope that they recognize that one plausible reading is that I'm trying to say to them, you're safe with me here. And I'm hoping that we all learn how to do that, not just follow rules but to be legible to others, that we're safe with each other in these times.

It's a big ask, especially in Florida where some people seem to still disbelieve that anything's happening. That won't last long. But if we're going to have a social fabric that can sustain us through all this, it will have to be based on our ability to read and understand the space we're in, and not just revert to mistrust and reductionist readings of each other. That's the kind of mistrustful, superficial reading that we've incentivized and valorized for years now, the kind in which we read charitably only when people are in our group, and we read uncharitably at all other times. And that's what we can't afford anymore, not that we ever really could.

\section{April 10}

I was going to ironically claim the hashtag \#covidchic, just to collect examples of how we can turn even a pandemic into an opportunity for personal style and aesthetic expression, thus taming the situation and taking our minds off of the real carnage and death in our midst. Maybe the revolution will not be televised, but the pandemic will be designed and marketed and probably even trademarked.

And then I discovered - I'm way too late, it's already being used, people are already vying for the coolest face mask designs. Sigh. Always a step behind, and irony has died yet again. 
May 9

As I walk before dawn, every morning I look for the point at which the night transitions into day. It's not a point, of course - just as there is twilight at night, there is "morning redness" at dawn.

Most philosophers who know the old German term for daybreak, "Morgenröte," would most likely think of Nietzsche's 1881 book that is usually translated into English as Daybreak. My own point of reference, though, is much older, to the German mystic Jacob Böhme's first book, in 1612, called Aurora oder Morgenröte im Aufgang (see Böhme 1977). To my knowledge, Nietzsche never mentions Böhme, even though Böhme was referenced in virtually every German history of philosophy for a hundred or so years before Nietzsche's book by that name. It's even stranger since, in my opinion, Nietzsche is the most direct 19th century heir of Böhme's, far more than those who are usually seen as following in his footsteps, such as Hegel, Schelling, von Baader, and a host of non-Germans like Coleridge, Blake, and Soloviev.

Anyway, it's Böhme's work that is most interesting for me. His idea of daybreak is more than just Reagan's “morning in America”, the time when businesses open and there's new economic opportunity and optimism for the American dream. It's something much more than that. Böhme had a vision in 1600 (in which he "learned more in 15 minutes than all the universities in the world could teach him in a lifetime"), and spent the next 12 years trying to make sense out of it. His vision was not so much some new revelation, a new message from God, but a new order of things. The familiar things in the world were still there, and the world was still a material place, not just an illusion, but the things of the world were linked together in a completely different manner than they seemed on the surface. By the time he gets around to talking about the morning, 500 pages in, he's deep into mystical language interpretation and cosmic metaphysics. TL;DR version: Morning is creation.

Well, so what? «Morgenröte» was Böhme's first crack at a lifelong project that started when he had his first visionary experience at the age of 25 . The project was to figure out how creation worked, not just as something that started off all that exists, but something that happens at each moment, renewing the world instead of rendering it to be a machine or a pre-programmed set of processes that simply ran through their code to their logical conclusions. He did this as a (heterodox) Lutheran, at a time of suspicion towards Catholicism and towards Calvinism. Lutherans distrusted Catholics, among other reasons, because their epistemology was one based in a hierarchy of people, reaching back in time and reaching up in power. If you were a regular Christian, you were expected to believe something because your priest said so, and because the bishop said so, and the pope. And they all based their ideas on figures going back over a thousand years. Something was true, in other words, because some external figure authorized it.

The Reformation in general resisted that epistemology. Lutherans, famously, had 
a religion of the heart, one in which you could approach God yourself. No priest needed, no pope, no prior authorities at all. And (here's the mistake that the Lutherans thought that the Calvinists made): no rationalized structure of belief either, effectively limiting the range of creativity in belief to what could be deduced from theological first principles. No, the Lutherans had something much more direct.

Böhme was heterodox, though, as I said. He was condemned by the local Lutheran minister after the Aurora came out. Because even a faith of the heart had to have some order and structure. Böhme was proposing something that more or less put power-hungry priests out of a job - a theology that could be alive and self-sustaining, yet organized, not just a free-for-all of personal whims and convictions.

The Romantics turned all this into some cosmic divine principle hidden within everything in the material world. The art is full of this - the divine light shimmers in everything, and morning is the time to see it. That was a lovely but tragic vision of the world, one always prone to corruption but also to its own blind spots, especially about what forms of life in the end embodied that energy.

But that doesn't detract from the initial question, about the morning and creativity. It's not just the exercise of individual will in the marketplace. It's not, on the other hand, getting with a program, whether that is a religious one, a political one, or something else, and contributing to the cause. It's not the mad tortured genius (whatever the Romantics might have thought). It's not innovation, it's not being cutting-edged, game-changing, paradigm-shifting, rule-breaking - kicking ass is old hat at this point. It's something else.

So, that's what I think about as I watch the sun come up every morning.

\section{May 18}

One thing I've been doing on these walks has been to introduce myself to some of the other regulars and get their names. "By the way, my name's Bruce." They have to be regulars (i.e., they need to have seen me out there multiple times). Bikers don't count - they go by too fast. People with earbuds in don't count - they're in their own world. Generally I don't introduce myself to women on the trail, because I don't want them to think I'm hitting on them (hold your horses with the "but I'm a nice guy" stuff, dudebros, and check with some women you know to find out whether they'd find it creepy).

So first there was Jim. Then Trevor, then Nakawa. Jimmy. Today it was Marie and John. I've clearly been infected by the narrative bug by Lisa [NOTE: my spouse, who is a creative writing professor], because I tell little stories to myself about these people. Jim was former military in my mind - polite to a fault, very proper, great posture. Nakawa - seriously, if this guy wasn't in some people-related industry he'd be wasted, because he's totally outgoing, friendly, interactive, all that good stuff. Jimmy: I was sure that he was a session musician in Nashville who had retired to Florida. Probably a guitar guy. Always a big smile, southern good old boy accent. Trevor: always had a "keep up the good work!" thing for me, or something like that. Very positive. And Marie and John - African- 
American couple, probably late 60s, sweet as they could be. I'm guessing that John was a former pastor or something. I only introduce myself to one a day (or one couple today) don't want to cheapen the experience. What I want to do, instead, is construct those little stories in my head.

And then, as the days roll by and we see each other more and more, sometimes a little more comes out. Jim isn't a casual runner, he's got a program. Because he's done a bunch of marathons. He was signed up to go to Greece and do the original Marathon route, but isn't sure that will be possible given the pandemic. He's got a hill day (yes, in Florida - it's the trail overpass over a highway, not much of a hill but it will do if you go up it 20 times). He's got a distance day. He's got a rest day and a weights day. He said he'd done one in Spain, ending up in "the northwest part of Spain". Oh, Santiago de Compostela, I asked? The traditional pilgrimage route for Catholics? He seemed very pleased that I knew about it. Clearly for Jim, some of this was not just about running, but was also devotional practice.

Trevor, with the encouraging phrases, told me today that he'd been laid off. He worked for a firm that did large-scale infrastructure projects. He was still upbeat - he'd been planning to retire soon anyway, so this was just the push to do that. He'd had a good run, he said; I said I could see that. Sometimes you don't know someone well enough to let out how you're really feeling about a momentous thing like this, while sometimes a stranger is exactly the person you need to say what you can't say to someone closer. It seemed to me that he was debating which one I was. The safe option was to stay upbeat, and that's how we left it.

Nakawa apologized for not being on the trail for a few days. He said that last time I'd seen him, he was timing himself (we didn't talk long at that time), and shortly after he'd seen me he took a fall and scraped himself up pretty well. He still looked scraped up. He was who he was, though - still upbeat, still asking how we were doing. He'd taken his wife and two dogs out on a run the other day. By halfway through each of them was carrying a totally exhausted dog, and eventually he just went home, got the car, and took them all home, where they limped around and slept for a day. He's a pharmaceutical rep, and still able to work from home, although he's not sure how much longer that will be possible. [NB: this was written in May, and at this point in mid September, I haven't seen Nakawa for a couple of months. And I do worry a little for the people I met on the trail. He's probably fine, but I miss his smile and his cheerfulness.]

My original idea was just to attach names to these bodies moving through space, to try to make it all just a little less anonymous. I wanted to signal in a small way to the individuals that they had been seen and appreciated, and would be missed if they weren't there. I wanted to signal to the African Americans that they too were part of all of us out there. I wanted to be a face and a name to Nakawa, to counter the suspicion that black men are under when they do pretty much anything in a public space. We are, after all, in the time of Ahmaud Arbery, who was murdered while running. When I see a cop car, I think, "if I were black I'd be worried". Well, he's black. How can he stay so positive 
and interactive when he lives in a society where people like me, middle aged white guys, suspect people like him of "fitting the profile" of all sorts of bad things? I don't know. But if attaching names to faces in public space helps even a little, it's worth trying.

Anyway, the little stories I construct for each of these people give way to reality, and usually it turns out that my stories weren't all that accurate, but they were a place to start. My inaccuracies show up my assumptions, sometimes my stereotypes, maybe even if I'm honest my latent bigotry or gut feelings about people.

Maybe too it makes the space a little more human. We're not all just interchangeable randomly passing bodies. I couldn't do this if I was on a bike (like I said, that goes too fast), or I think even if I was running instead of walking. So there's something to be said for this pace, apart from saving my knees from a pounding on pavement every day. Every speed, every pace is its own world, with the flows and textures unique to it. This speed is, I think, the world of people who have names. And stories, first mine and then their own.

\section{June 3}

Your morning red sky bridge. [picture of a walking overpass at dawn]

It's all about the light. The thing is, every artist for the past few hundred years has known that. But it's meant different things. The Romantics had a light that seemed to come from within everything, indicating the spiritual unity of all the diverse world. The Impressionists saw landscapes and buildings at different times of day and therefore saw the light as a passage of time, a cycle, an individuating thing. With the dawn of perspective in the West, centuries before, light was all angles and bounces, creating lines of brightness and darkness, and hence the illusion of dimensionality.

In some cases, light is the harsh scalpel that divides the world into viewer and viewed, into objects separated from each other (sound, on the other hand, keeps things in their context, and by implication at least keeps us in that context too). When I see, I see things, whereas when I hear or smell things are more easily mixed together and are more likely to affect and influence each other. And touch, well, that's a whole different thing, very specific, very intuitive. If what we see is potentially far away, what we touch has to be close.

There are more, especially if we leave the vocabulary of light in the West and take in other visual traditions from around the world.

So, I keep watching the light as it emerges in the morning, and wonder whether any of these is behind my interest.

\section{June 17}

Your morning houses by the lake.

It's not all nature and water on the one hand or ticky tacky boxes on the other. Here in Florida, we tend to privatize things like lake access. This struck me when I first moved to town - when you fly in you see how many lakes there are in the area (check out Google 
Maps for central Florida, if you don't believe me - it's quite amazing how many there are), but if you are driving around you could be forgiven if you thought there weren't very many.

Orlando isn't one city, but a bunch of them that grew together. Orlando itself is just about $280 \mathrm{~K}$ people. The Orlando metro area, on the other hand, is about 2.4 million. There are almost 50 towns that grew together, each at least $10 \mathrm{~K}$ people (and some significantly larger), and many more smaller ones that are part of the area.

What that means - no central planning, at least not historically. Many small city centers. Many local planning areas, with their roads and infrastructure, all of which grew together. And, when it comes to lakes, they were either the center of these small towns, or they were parceled out to landowners and the nicest places in town were built next to them. So, you rarely can drive next to a lake, since property abuts many of them. That's what is happening in the pictures here - Lake Jesup had much of its shoreline bought up decades ago, and so new development happens in what was the marshy inland. The stratification of wealth in the city takes a very different pattern compared to an urban area that has a different history to it, with fewer bodies of water and fewer small towns that grew together.

This geography affects everything (as is the case everywhere, of course). It affects the location of wealth and poverty. It affects mobility (this is a hard city to get around in - few straight lines anywhere, lots of adjustment at the edges of these small towns as they meet up). It affects community - if it is hard to get around, it is hard to meet up, or at least there's one more barrier in the way to seeing people. It affects identity - just as the metro area has this fragmented past, it also has a unified image to the world holiday capital, theme park destination. So, even though there is lots of history in the area (some of it worth being proud of, and certainly some of it to be ashamed of, like lynchings, segregation, murders), that's hard to see because of the fragmentation of the geography.

Geography isn't destiny, of course. Los Angeles is also comprised of lots of small places grown together (although not with the lakes we have here). We are also not cities with a past built on a single industry, for better or worse (Pittsburgh, Detroit), and so we never had to go through the difficult loss of that single industry and a reimagining of what we could be.

Maybe that's still to come, if travel is curtailed due to continuing pandemic threats, and the tourist industry stays depressed for a long time. But a lot of those jobs aren't the same as existed in the industry towns, good middle-class jobs that could sustain a family. Those days are gone. We're a service economy here, and our relatively low median income shows it. No one here has thought about what we are post-Disney and post-Universal, because those places seem like they're going to go on forever. But of course they won't. Nothing does.

A lot to get out of a bunch of lakes, right? Even though there's no geographical determinism, our history of place does matter to who we are, to who gets those places by 
the lake and who doesn't, to how the story is told about what this place means. Being a carpetbagger, I'm not likely the one who's going to get to tell that story. As with most of the south, if your family hasn't been here for at least 5 generations you're not really from here (to be fair, in our service economy, there's less of that than, say, further north in Florida).

But even if I'm not the one to tell the story, it's worth thinking about what goes into telling it. And, it seems to me, lakes are a big part of that.

June 29

And it was an early one today - out by 5:15, at the lake by 6:30, 10 miles total.

Weird encounter: it was about 5:25, totally dark still, and this guy rides up behind me on a bike. Starts talking. WHY ARE YOU TALKING, I'm saying in my head. He's a political candidate, it turns out, and he wanted to introduce himself. In the dark. Before 5:30 am. He doesn't yet have a website, he says ("those things are hard! I can do Facebook, say do you know any kids who would build a site for cheap?"). He's Mike someone. "Quit" his job a couple of months ago to run for office. Living with his mom. (I am not making this up. He said all this.) He did not identify a party. Did not tell me any of his ideas, or what he wanted to do. He had a large laminated card, lots of red white and blue, very little information.

And he's discovered day trading. "It's easy! You can do really well!" Has parlayed \$7K into \$27K he says.

I had many questions. I did not ask any of them.

\section{June 30}

Your morning summing up. The usual bucolic splendor, animals minding their own business or getting into each others' businesses, nothing much new. And yet, still worth looking at and listening to.

This is the last day of the month, though, and so time for numbers. The total for June is just a hair under 290 miles - would have broken 300 if this month had 31 days. It was a long week to get to that mark - 9.5 miles today, 10 yesterday, several other days at 9 miles.

And this is also the $1 / 2$ year mark. Every day of the year has been on the trail, at least for a few miles, and during the pandemic the mileage has gone up. Total distance for the half year: 1386 miles, or about 2230 kilometers. EDIT: walking from my house to Toronto would be 2037 kilometers, as Google Maps informs me, so I guess I could have done that instead over the past 6 months.

The thing is, I don't think of myself as a hardcore walker. There are people who do a lot more, and runners who do a lot more in the time I take (sometimes up to 3 hours in a morning). Some of these are probably reading this now, thinking yeah, I remember when I was there. Good base to start the real training.

The point is still what it always was - to just get out and observe. A friend pointed out a quotation by Graham Good in The Observing Self (1988) that I didn't know. He makes a connection between the genre and the activity: "in some ways the essay is essentially a 
peripatetic [!] or ambulatory form... walking [is] the perfect analog of 'essaying'".

So every morning I walk an essay, in that classic sense of essay. Maybe also in the classic sense of walking. Some of these essays have a neo-Romantic feel to them look at the beautiful nature. I don't really mean them to have that connotation, but it's hard to avoid it. I'm more interested in the closely observed, whether that has those transcendental echoes or not. Some of those walked essays are comic, some are tragic, some are belle lettres I guess, some are punk, some are jazz. The cast of characters has grown. Some have names, most don't. Some make cameos, others are regulars.

The walk is the purchase price for the ticket that lets me in the door, to be able to read and write the essay. That makes it sound like an obligation, a cost, and it's not really that. I mean, if it was, I wouldn't be waking up before 5:30 every day and just getting out of bed and starting out. I'd be dragging my feet. I've not yet reached the foot-dragging stage. I'd like to think that in all this sameness, the same path, the same characters, the same sunrise, there's something new all the time, if not on any given day, at least as an arc across many days. And it doesn't hurt, I guess, that this is the only time I'm out of the house these days.

I'll keep walking and writing for now. Nothing is forever, including walking. I've got sunk costs now (or maybe it's just a fear of breaking a streak), in my unbroken record of being out there, so the more days I get in a row, the harder it is to just take a day off. But it's not like it's a chore right now.

\section{July 12}

Your morning swamp walk. It's not all lakes, paved paths, and sunrises here. Sometimes it's cypress swamp.

I've been lax in posting of late - fighting with a new computer. I think we've come to an understanding - it will do what I want, and I will give it more RAM. Seems like a fair trade.

"Everyone complains about 2020. It's my best year in a long time." Yesterday I ran into Tim. Young guy, walking his dog Allie. He had his right arm in a sling, and I asked him about it. I expected to hear about some accident, maybe a fall or something. Turns out he had been in an accident, but in 2017. Was almost killed by a car when he was riding a bike near the university. He credits his mother with his recovery, because his doctors had more or less given up and wanted to put him in hospice, and she wouldn't let that happen. But he lived. It took him several years, but he's also walking, clearly, and a good distance at that.

It's his bestyear in a long time because he's been near death, and then in recuperation, and finally now he can live on his own again, and he can walk, and he has a dog, and there's a future when not that long ago it seemed like folly to hope for such a thing.

Doesn't mean that things aren't crap out there. Doesn't mean that we don't have an existential threat in the White House, and rampant white supremacy and misogyny and 
all other forms of fear and hate, and people dying when they don't need to. Doesn't mean things aren't really bad, and hope is hard to come by many days. Maybe I'm just struck by the banal realization that it could be worse, and that being on the point of death like Tim was puts everything else in perspective.

There are people at the point of death, though. Not me, not right now, but it could happen, and I read every day about those who get COVID-19 and don't make it. Many die isolated from those they love. Some of them mocked the masks and the directives, and then succumbed to it themselves, wise too late. $135 \mathrm{~K}$ dead in the US alone [N.B. at the time this goes to press, around $200 \mathrm{~K}$ deaths in the US and closing in on a million in the world], and governors and politicians telling us that we'll just have to get used to it, it's not so bad, it's the new normal, it's more important that schools open and businesses open and by the way, we're going to make it so you can't sue anyone for our bad decisions because who could have known, really?

Best year yet. Well, not for everyone, but I totally see why someone who came back from the brink of death, a broken body with little hope, can feel optimistic in these days. He deserves every bit of that optimism. I just wish I could bottle some of it and take a sip when I need it.

\section{July 26}

I read an article that claimed that there's not just one kind of COVID-19 denier. SMH. These are all part of the reason why the US leads the world. (We're Number One!) In infection and death rates, that is. (Oh, right, never mind.)

Some of this comes down to the fact that there's really no country left here, that is, no shared project that anyone can agree on. There's no public, as in public good, public service. The word "public" exists, of course, but the concept doesn't.

Here's a case in point - at the end of one of my walks recently, I was walking in the ditch on the nature trail. Someone asked me why. Was I afraid of the bikes or afraid of catching the virus? Notice how this question was framed - I must be afraid of something, so here are the two main choices. Choose one.

I responded that I had someone to breath each others' air. And, if someone else followed my lead and went off the trail on the other side, the risk would be lowered even more (it rarely happens, but hope springs eternal).

In other words, me going off the trail is a form of care for everyone there. It's a recognition that I don't always have to act in my own self-interest, but I can act in the interest of others. A very small thing, going in the ditch (and, in fact, sometimes preferable, because walking on dirt is often better than walking on pavement anyway). Minimal cost to me, lowered at home who was high risk, and I was going to do everything in my power to not bring the virus home. Not fear, care.

And, there was another form of care. If I go into the ditch, it's because I'm making a calculation in a specific circumstance about the levels of risk for everyone there. Maybe 
there are other walkers, and bikes coming in front and behind. I could continue walking on the trail, but going off the trail lowered the risk level for everyone. If everyone else just did what they were doing, we'd all be less likely risk for everyone. But it requires that I be aware of the public, that is, the collective risk of everyone, not just my own risk.

And, it also requires that I set aside the idea that my actions are about personal character. That's what the charge of fear trades on - I'm not standing up for myself, I'm backing down in the face of threat. But am I? What threat? The virus? It's not going to be vanquished by me standing up to it that way. And, my masculinity is not going to be established by charging ahead, no matter what risk there is for others, and demanding that they be the ones to move, not me.

I see this constantly in the US. Individualist thinking, individualist interpretations of action when there are other interpretations that involve collective good rather than just individual advancement of personal interests. And, while you can probably find this individualism more intensely felt on the political right, it is distributed across the political spectrum.

The public is a hard concept for Americans to feel in their guts, even if it's pretty easy to explain like I have here. It's not that people don't get it, it's that the default account of the world doesn't go there first. It goes to self-interest and individualism, and everything that comes along with that. Praise and blame. Character. Leadership. Lots of other limited ideas that make me cringe every time I hear them, not because they're bad in themselves, but because they come from a view of the world that starts and ends with individuals.

You can care about others, of course, but only to the extent that you are connected to them. Family yes, neighbors maybe, coworkers not too sure, others that look like you ok, others that don't look like you or sound like you or fit into your understanding of things definitely not. The world is just your own individual self, extended as far as it will go but no further. There's no public, just little versions of me out there.

So anyway, the guy who gave me two options which were both versions of fear, agreed that taking care of someone you love is a good thing. We didn't really get to the idea that taking care of those you don't love, or you don't know, is also a good thing. My guess is he wouldn't have thought so, unless maybe he could get some credit for it from people he cared about.

"Who is my neighbor?", they asked Jesus. Turns out, everyone is. And I take that to mean that the public matters, not just individuals who I see myself in, to some extent.

\section{August 28}

I accidentally went 11.5 miles on the morning walk today. Almost a half marathon.

How does one do this accidentally, you ask? By having one's head up one's butt as one is walking, and missing the turn one was to make, and only realizing said error a mile or so later, and by that point thinking, well, might as well just keep going around this big loop that I never take because, let's face it, that's just pushing it in Florida in August 
when even the dogs are being pushed around in little strollers because it's just too hot and humid for any sane person to be out there but you're out there anyway because you are ruled by a stupid little device on your wrist that tells you that you should be getting exercise every day and if you miss one you've broken your streak and then you might as well just give up because you'll never get that little endorphin rush of seeing that you have one more day in a row than you had the day before and you're addicted to collecting things even if they are meaningless but they give you some sort of continuity in this weird time and OMIGOD my legs are aching but there's no one with a little stroller to wheel you home and give you a drink with an umbrella in it so you'd better just suck it up and do one more mile because otherwise you'll just crumple onto the sidewalk and start sizzling like an egg on a frying pan and we can't have that now, can we?

That's how it happens.

\section{Midnight Pandemic Musings of a Psychotherapist in Love with Philosophy (by Eka Kaznina)}

Unpredictability! The category which separated knowledge from opinion in the mid of 20th century! Juvenal, the Roman poet, author of the phrase "rar avis in terries, nigroque simillima cygno" (literally: a rare bird in the lands, and very like a black swan; symbolically: an impossible event has higher probability of occurrence, than a meeting with a black swan) would be very surprised to see a black swan alive.

On the basis of Karl Popper's theory, Nassim Taleb (2007) asserted the Theory of Black Swans (TBS). According to Taleb, the criteria for identifying this type of event are the following: 1) An event is unexpected (for an expert); 2) The event is fraught with significant consequences; 3) After the occurrence, retrospectively, the event has a rationalistic explanation, as if the event had been anticipated.

Beginning from December 2019, a new Black Swan type event, pandemic -- burst into our lives! Taleb defines practically all significant scientific, historical discoveries, political events, achievements in arts and culture as Black Swans. For example, World War I, the introduction of Internet, the breakup of the Soviet Union, the 9/11 September attacks are considered to be Black Swans.

The pandemic can be regarded from different perspectives. Few of them are: the perspective of the amount of people infected and deceased, the loss of loved-ones or the loss of taken-for-granted liberties. We can consider the key strategies of population behavior in different countries, or look at the process, addressing the four existential inevitabilities, four sources of anxiety, according to Irvin D. Yalom (1980/1931'): death, loneliness, freedom and senselessness.

The last one seems the most attractive to us. Collision with the four givens of existence mentioned above in the frame of the pandemic cause anxiety, due to the ambiguity and 
unpredictability. Somebody, thanks to the pandemic, felt his power over his own life and death, and over those around him, due to his having put on disposable gloves and mask when entering a store once a week. Adults returned to the same pattern when they lost their normal forms of behavior: "Do like this and you are good/safe/valuable".

Within sight of death, life acquired distinctness as a singular value, which, under usual conditions is a practically unachievable task. In psychotherapy this is called a codependent position (accepting and following rules without critical analysis). Some people, in contrast, did not acknowledge the virus (death), and continued to lead their habitual life without reducing the amount of contacts. They suspected the state of conspiring, with the end goal to get everybody chipped, so as to control the whole of society, and they demonstrated in protest against this. This is the example of the counter-dependent position.

The issue of loneliness is closely related to the issue of death. Awareness of the divergence of needs of close people in close contact causes the feeling of loneliness, as a lot of people resolve the loneliness problem through belonging or merging. The possibility of becoming aware of self-singularity and gratitude to someone for communication (personal contact) - is one of the possible advantages of self-isolation.

At first sight, the category of freedom would appear clear, however the issue is rather complicated. One would think there is nothing easier than freedom. Very often freedom is understood to mean the possibility to do what one wants to. For example, at sessions for drug addicts there is an exercise, which involves the addicts becoming the "bosses (owners)" of "slaves" who obey all their orders for 5 minutes. After this session, the addicts share their emotional experience, defining freedom as the opportunity to do what they want to, without any responsibility for what is going on.

Erich Fromm (2013) speaks about negative and positive sense of freedom. Negative sense of freedom is based on external limitation. Charles Taylor (see, e.g., Askland 1993) calls negative sense of freedom the "principle of opportunity" because it provides you with access to a number of desirable possibilities regardless of whether these possibilities are used by you or not. Taylor defines a positive sense of freedom as a "concept of exercise", because you are making a conscious choice out of all available possibilities in favor of the one which particularly meets your vital priorities and values. A negative sense of freedom can be described as a number of open doors for you, while a positive sense of freedom is the possibility to enter the necessary one.

The same principle works under the conditions of a pandemic. Readiness for a change or an event is, as a matter of fact, readiness for indeterminacy or readiness for a choice, Dmitry Leontyev says in the essay "From Social to Personal Values" (Leontyev 1996). It is a question of readiness for different possibilities, readiness to do and implement here and now the choice not predetermined beforehand. For E. Sokolova (2014) tolerance of uncertainty and ambivalence can serve as evidence of the individual attaining maturity, constancy and integrity of the Self, being able to cope with the anxiety. 
In conclusion, a tolerant attitude to uncertainty and possibility to cope with unpredictability most probably turns out the most efficient outlook for personal development and resistance to stresses. The essence of such an attitude is to reject the childish illusions of stability and certainty of worldview, and to elaborate a more grownup position of acceptance of uncertainty, the other side of which is the discovery of new performances. Readiness to meet and accept unpredictability could be considered as maintaining a link to reality.

\section{Experiences in the COVID-19 Outbreak As an Exchange Student from South Korea to Poland and Back Again (by Kim Jihyun)}

COVID-19 started to spread in South Korea from the middle of January 2020 (a woman who had visited Wuhan was confirmed to have been infected on $19^{\text {th }}$ of January, which was the first case in South Korea). We started to wear face masks from that moment, in public places (however, it was not mandatory).

By the end of January, Korean universities took some actions to interrupt some programs which deal with Chinese schools and students. University policies depended on such schools, e.g., Dongseo University (private) indefinitely postponed the 1-year training program of Chinese international students (whose school was in Wuhan), and tentatively stopped the intercultural program. Pukyong National University (public) canceled the Korean language training program for international Chinese students, and recommended that students and teachers who had visited China should self-isolate. Busan University of Foreign Studies (private) also canceled Chinese students' exchange program in the first semester. Other public and private universities mostly started to investigate people who had visited Wuhan and China and required them to self-isolate for 14 days, or to delay their entrance to Korea.

I left South Korea and took a flight to Poland in February $21^{\text {st }}$. I was concerned that my exchange program would be canceled due to COVID-19, but I got an email that it wouldn't be cancelled. I went to students' orientation and took real-time classes at the Adam Mickiewicz University for a week, however, soon I got a notification that students from particular countries including South Korea have to self-isolate for 14 days from the day we arrived Poland. So, my friends and I didn't go to classes from that moment and until now, because the whole university delayed traditional teaching and replaced it into online classes.

Korean universities delayed the start of classes and gradually switched to online classes, too. Until now (end of May), all schools are going online - primary, secondary, and high schools - except some university courses that need practical training, and from $20^{\text {th }}$ of May students in the last year of high school started to go to school because they have to take university entrance exams at the end of this year, and therefore needed to take in- 
person classes (they study with masks, rearrange their desks with distances, and check their body temperature when going through the entrance of the school). Today there are big and small movements in each of the Korean universities, which requires the return of the tuition because the quality of the online classes is lower than the in-person classes. Therefore, some universities decided to return part of the tuition to their students.

My home university in Korea planned to send 40 students abroad this semester, but due to COVID-19, the situation changed quickly, university by university. Therefore, the manager of our exchange program made a group chat among us, to share current situations in each school abroad. From that chat and from some news articles, I got information like the following:

- The Japanese government banned Koreans from entering Japan at the beginning of March 2020. Therefore, some Korean students who planned to participate in the Japanese exchange program got a notification that their program had been canceled. Japan also banned issuing Chinese people with Japanese visa.

- Students who applied for the Taiwan exchange program \& China's exchange program also got a notification via email that their programs had been canceled.

- A German school just canceled all their whole classes in the first semester, therefore the exchange students had to give up their opportunity.

- Three of the American Universities changed all their courses in the first semester to online classes, and recommended that the exchange students go back to their home country.

- One of the students who went to an Irish university also came back to South Korea because they recommended that each student should go back to their home country. And because most of her foreign friends went back to their home country, she thought there was no point in her staying there. (Her biggest dream and purpose was to make foreign friends and spend time together, plus to travel among European countries. However, in this situation all of her friends went back and she wasn't able to travel either.)

In my case, when UAM delayed traditional classes and before Poland closed the borders between countries, I went to Berlin with my Korean friends at the very beginning of March 2020. Our families in Korea were worried about COVID-19, so they told us to take face masks during our journey; however, we didn't wear them at all because in Europe people didn't wear masks at that time. We heard that if we wore masks, people would treat us as infected with coronavirus so we might experience more racism. Even though we didn't wear masks, we still experienced racism in Berlin because we were Asian. When we were walking down the street, people imitated Chinese language behind us (people cannot distinguish Chinese, Japanese, and Korean individuals; we can distinguish each other by the appearance or styles) or shouted 'Corona!' at us.

When I went back from Berlin, I couldn't wear or buy face masks in Poland, either. I was worried, and I didn't want to show people that I am Asian. So I mostly wore a cap to 
cover my face when going out. There is an online community site which is composed of Korean residents in Poland, and from that site I saw an article from March $9^{\text {th }}, 2020$ that a Chinese businessman in Wroclaw was attacked by people due to the COVID-19 situation. I didn't experience more racism, but my friends faced diverse situations; people stared at them uncomfortably for a long time and avoid them, say 'corona' while passing by, cover their mouth and nose when passing by, cough towards Asians, etc. Moreover, there is a group chat on WhatsApp for the AMU Erasmus students. In that chat there were many rude students who made fun of Chinese and Italians, treating them as a virus, too (so I didn't really check the messages). This kind of situations did not happen only in Poland ${ }^{1}$.

As this article originally appeared in Korean, I will translate one of the episodes. In this article, even professors were rude to students from South Korea, too (Student \#A and her Korean friends who are studying in Ireland experienced racism during the class ${ }^{2}$ ).

According to the transcript, the professor asked the Korean exchange students during class, "What is the currency in South Korea?" When the Korean exchange students answered "won," the professor laughed and shouted "corona" several times. "I was embarrassed at the moment, but the Corona may have inadvertently come up in his mind because it was a Czech monetary unit," \#A added.

"But when I was away, there was a short class in which students had to say their name in front of the professor. At this time, my friend hesitated whether to say her English nickname or Korean name," \#A continued.

The professor asked: "You don't even know your name, is it because of the coronavirus infection?"

"I thought the professor's joke was too much," \#A said. "I was walking toward the professor to sit down after the break time. Then the professor suddenly coughed, covering his mouth with his clothes. Looking straight at me, he said "Corona is coming." I was so embarrassed that I asked, "Are you racist?" Following \#A's protest, the professor said, "There was no malice but I apologize if it was uncomfortable. However, I tend to joke under any circumstances." \#A reported in the Youtube video: "Since then, tears have filled my eyes. I had a hard time holding back my tears because I was angry (...) I got an apology after the class, but the professor still stuck to his shameless attitude, saying, 'I make this joke to Italian students as well."

In fact, in the transcript, when a professor says "Corona Is Coming" during class, it is clear that other students' also laugh. A professor at an Irish university made a mockery of Korean students through racist remarks. At that time, the spread of COVID-19 in Europe was not serious, but the recent video of \#A's testimony and transcripts has spread around YouTube, causing public outrage among viewers.

Moreover, the German media also reported that the spread of COVID-19 has

1 See http://www.pharmnews.com/news/articleView.html?idxno=100363

2 A transcript of a professor's voice at a university in Ireland was released in Youtube 1:17-1:37, https://www.youtube.com/watch?v=GT-tUn70x54 
increased the threat of racism to the Asian community. Therefore, concerns grew at the Korean Embassy in Germany. The Korean Embassy recently distributed leaflets containing emergency phone numbers and advice to Koreans living in Germany, saying it would help victims of racial discrimination.

Due to these stereotypes towards Asians and the risks of infection, many of my friends who applied for the exchange programs in European \& American countries started to go back to Korea from the middle of the March. I also considered going back to my home country from March, but I decided to stay in Poland because at that time the situation was not so severe in Poland. I took some vitamin pills and ordered traditional Korean medicine from the Oriental hospital in Wroclaw, which is good for strengthening the immune system. In April my Korean friends in UAM started to prepare to go back to South Korea. One of my friends left Poland on $15^{\text {th }}$ of April, and four of my friends left on $22^{\text {nd }}$ of April. Then I also considered going back to South Korea. As my family told me, "[South] Korea's situation is getting better, but in Europe it is getting worse. If you get infected in Poland it would be hard to manage your treatment, because you are not able to speak Polish - you will have a hard time communicating with people who don't speak English." I also got tired and bored of staying in my dormitory for most of the time, I couldn't travel somewhere else because of the fear of infection and the closure of the country borders. I couldn't go out to eat and shop (I heard this is now possible). To be honest, I actually got stressed in living with my roommate who was very kind but had a different living pattern and culture from me. We stayed the whole day together in the small dormitory room, every day. I missed my family and my home a lot, even though it was bad to give up my experience in Europe, because I live in a country which is far from Poland and it was a rare and special experience for me.

So I booked a flight to Korea and the departure date was May 1st. However, I received an e-mail on $24^{\text {th }}$ of April that the flight was canceled, so my return had to be delayed. But since all of my friends returned home on a special plane, I decided to reduce my luggage and prepare so that I could leave anytime, and waited for the special plane. Then, on April 27, the Korean Embassy in Poland issued a notice that a flight from Warsaw to Incheon is on April 29. I packed up and left the country in two days. In the special plane, I received a liter of water (instead of a cup of water from the stewardesses) and packaged sandwiches instead of an in-flight meal.

Upon arriving at Incheon International Airport, people measured my body temperature as I entered a gate which is dedicated to inbound travelers. Incoming people with fever symptoms were examined separately, and if they did not have them, they moved on to the next stage. We had to install a self-diagnosis application (for our health report) and self-quarantine protection application (which tracks our location) on our smartphones with the help of voluntary military soldiers, airport staff and doctors. Staff called the guardians of the arrivals, including me, to confirm their entry.

People living in Seoul (the capital city in South Korea) went home by car or taxi, 
while people living in other areas took a private bus (only for the incomers) to the train station. At the train station, we also used a gate and ticket office exclusively for arrivals from foreign countries and boarded the train along with the leader. We also used separate, isolated seats only for the incomers.

After arriving at Busan, the city where I live, I got a free coronavirus test, following people's guidance. (After 2 days, I got a call about the results of the test, and I was negative). From Busan Station, I arrived home by taxi only for the arrivals. The taxi drivers were public volunteers and all the taxi fares were used for the cities. I had to self-isolate for 14 days from that day. I couldn't go outside because the application I installed when I entered Korea was supposed to track my location. Quarantine violations were to be fined up to 10 million won (it's about 33,000 PLN). I lived in a room with a bathroom in my house and had to maintain a two-meter distance from my family. If conversation was needed I had to wear a face mask. A disposable thermometer, mask, hand sanitizer and several garbage bags were provided by the health center. Although it was not the case in the area where I lived, I heard that some areas provided food for the people who are self-isolating. And twice a day: before 10 a.m. and before 8 p.m., body temperature and symptoms had to be measured and reported to an official through the application. When I wrote down questions about something, the official in charge (every incomer was assigned to our own officials) called me and answered.

South Korea, where the number of confirmed cases of COVID-19 was on the decline, has recently seen a rapid spread of the virus again, when an infected person visited a club. But there were also gay clubs among the local clubs, so it was difficult to track the visitors. (Korea is not well aware of or cares about the well-being of homosexuals.) People wrote false names and false cell phone numbers in the guest book, and it didn't work even if club visitors were asked for voluntary registration. Therefore, the government tracked visitors using credit card details, accompanied people's statements, and the wire service base station's information. Since the club was in an area where many foreigners come and go, they sent an emergency notice that is translated for 114 foreign embassies in Korea to find the foreigners who visited the club. It also posted a related notice to nearby foreign community centers and sent text messages and e-mails to members of the Global Village Center. If people voluntarily announced their visit to the club, they would not be asked which club (the club's name) they had visited and could be inspected anonymously. However, if they do not receive an inspection after receiving a call from the quarantine authorities, they will be fined.

South Korea started tracking the movements of confirmed patients from the early stages of the COVID-19 outbreak. This had a positive effect on the wider spread and prevention of infection, but in the early days many people on the Internet were hurt by the exposure of too much personal information and its release. I think some foreigners may have felt uncomfortable about the government's thorough pursuit of people's identities and movements in the club case, because they might feel the freedom of anonymity 
is unprotected. However, the majority of Koreans seem to feel the need for this and appreciate the thoroughness of the government, because it is a pandemic. I think South Korea was unusual in the way that it coped with this pandemic precisely for this reason.

\section{A Dispatch from a Different World. To Adapt, Or Not to Adapt, That Is the Question - Reactance in Times of Crisis (by Claudia Ammann)}

There is a question: Who is better equipped to survive a crisis - the adapter or the disrupter? In the early months of 2020 , after it became clear that a virus was spreading in a pandemic fashion from China into all corners of the world, a crisis was announced and guidelines - which soon became directives - were disseminated, reminding people to stay at home and protect themselves and others from infection. The way people have reacted since then has been a constant source of fascination to me, leading me to wonder who, and what kind of behavior, will survive this crisis better.

There seem to be two distinct reactions to a crisis mode: You can either adapt and behave as instructed, or you disrupt and behave in the opposite way. In crisis mode when the announced guidelines remind you to essentially 'restrict' yourself, you seem to have no chance at all to behave differently. You comply. Or, on the contrary, you appear to have all the options available that are different to the prescribed ones, because the advice you should comply with is, in your mind, not meant to do you good. The question is: What is the better strategy, and who has the better chances of surviving a crisis like this - the ones who comply or the ones who show reactance? Common wisdom tells that in a crisis, such as the present one, you are better advised to adapt if you want to survive well. Therefore, I usually tend to believe the adapter is the one with the better chances. However, right now, I am inclined to think, the disrupter has good chances to win this bet. The following lines invite the reader to contemplate the qualities of both strategies, and then to reconsider whether it is better to adapt or to disrupt.

The disrupter: "Suddenly the man has hobbies - could anyone tell him he should stay at home,"3 says the son expressing the view that the old man should stay protected against the virus. The son, who works in an emergency unit at a local hospital somewhere in the middle of the United States, expressed his worries about his father who would not follow the official advice to stay at home. The father, who after being forced out of work, was sitting day in-day out in front of the TV, was doing nothing. But, following the Coronavirus COVID-19 warnings, he left his armchair, and suddenly became pro-active. He started to paint the walls, cleaned the house, did DIY-shopping, and went out for a beer at a bar. The son, more and more concerned and in fact more and more puzzled over the behavior of his father, sent a tweet 'out into the world' to share his concern, and

3 The story refers to a broadcast on US American TV (MSNBC, The Rachel Maddow Show) in April 2020. 
became nationally and internationally known on TV. Was that old man just stubborn and unwilling to cooperate, or did he show a healthy reaction? What has gotten into him?

The grandmother, not allowing anyone to interfere with her decisions, turning a blind eye and a deaf ear to all advice to physically distance herself from others, met with her grandchild. While being critical of other people's misconduct and ignoring the rules, she apparently did not recognize that the new rules also applied to her. Other people not complying - that is one thing. Her transgression, however, the taking-for-granted and just-being-easy about her own activity - that is another thing entirely. And the family, perplexed and disconcerted, was wondering whether they can call her disrespectful or disdainful of a new social norm, or whether they are the disrespectful ones when not paying her age the necessary respect. Then, one of them remembered that she just had done exactly the same thing more than half a century ago, when hurriedly marrying seven months before the birth of her first child, when society and Zeitgeist forbade sexual intercourse before marriage ${ }^{4}$. Was it that she just would not listen and comply, then and now? What has gotten into her?

As I was on the phone with my mother-in-law, after listening to her lament about not being allowed to leave the house, I asked her:

"Did you go into town at all last year?

She: No. .... [she pauses]. But, you know, I could have.

Me: And now you can't?

She: Yes. [we both pause]

I again: So it is like, when everything was allowed - you didn't. But now, with everything being prohibited - you can.

She: Oh, yes, that's right. It's exactly like that.

The adapter: "Suddenly it works," says the psychiatrist in a TV conversation ${ }^{5}$ and takes great pleasure in it. "Suddenly we can do, and can work with them, which we couldn't do before. Suddenly we see the exact same people who would have feared almost everything before, and would not have even left the house, are now taking a phone call," while referring to telemedicine, a new type of psychotherapy that was viewed with great skepticism before, but not so any more. According to the psychiatrist, it is the desire for control that makes it difficult for some people to adapt. However, adaptability, the psychiatrist continues, is the most intelligent capacity people can have. The capability to prioritize the new and relevant, and thus the ability to be open-minded, is a tool that enables us more than it restricts. Those with this characteristic will only thrive and evolve, while those without will remain there where they are.

4 The story refers to the author's experience as consulting psychologist.

5 The story refers to a broadcast on Swiss TV (DRS, Corona and the psyche - anxiety, stress, and loneliness) in April 2020. 
To adapt, or not to adapt?

Reactance is a psychological defense reaction ${ }^{6}$ in which the person feels resistance to an external rule, regulation or outside pressure, to which he or she reacts in a resisting, or opposing way. In attitude as well as in behavior they express their resistance to what they feel is external pressure, constraint and restriction on their personal freedom. The person behaves in potentially unexpected manners, as they feel their personal choices and liberties to be threatened. It can be argued that in the present crisis those who suddenly became active and started to act against all well-intended guidelines and crisis recommendations acted so because of reactance. Apparently though, they also became disrupters.

Good meaning voices, which belong to my professional peers, would tell me to see the things in perspective. They would tell me that the best strategy for surviving a crisis depends on the circumstances. The disrupter would surely be better equipped only in times of suppression and oppression, during periods of despotism, unjust rule, or tyranny. The adapter, however, is better adjusted in cases of acute crisis and catastrophe. That is to say, in a long-term crisis you ought to do better when, for example, you think critically, act self-consciously, and not adjust enthusiastically or surrender - in other words you allow yourself to disrupt. In a temporary, or short-term crisis, however, the adjustment makes you better equipped to surviving. In a nutshell: an acute crisis tells you to adjust; a chronic crisis allows you to disrupt. In other words, you need to look at the circumstances to evaluate which strategy is the better one.

Yet, if true, and the answer is as simple as that, and you just need to react to a particular circumstance only, and act accordingly, then why would the disrupter choose to behave the way they do, contrary to the case, or psychological defense mechanism as it concerns rather a motivation or attitudinal state than a behavior.

When textbooks about crisis intervention tell us that the ones who adapt in an acute crisis will have the better chances to survive, then why do the disrupters believe their strategy is the better one? When times of adversity tell us that it will be the nonconformists, the reactant, the rebellious, defiant, and insubordinate, the ones that are sticking out - the so-called 'English tall poppies' if you wish - who are going to go down and under, the first who will fall victim to misery, then why in heavens name do they believe that their strategy of disrupting will bring them further than adapting? Why do they behave as if we were living under constant crisis, with oppression, despotism, and unjust rule, when in fact this crisis is supposed to be temporary?

The question remains: What should one do - adapt or not?

6 Or psychological defense mechanism as it concerns rather a motivation or attitudinal state than a behavior. 


\section{To adapt!}

Reactance, or disruption, can unveil uncooperative behavior that had previously been there, but which had never been important enough to be bothered with. The unveiling, however, makes open what had been concealed, and as a potential effect, the shared belief among the community will be undermined. However, it seems unclear whether reactance undermines the shared belief, or the uncooperative behavior before. Some psychotherapists would argue: both. Others would argue that the one comes from the other. But many would probably agree that both behaviors are 'unhealthy' for a community that holds and shares some essential values.

Reactance can be regarded as a risky, individualistic principle that undermines a common understanding of shared beliefs and shared principles. Someone ignores a rule that normally concerns all. The underlying principle is one that envisions everyone as being equal equipped with equal rights and equal obligations. The implicit understanding is that everyone should participate accordingly, as equal participation with regard to rights and obligations bears some responsibilities for everyone. Yet such a rule is ideal or even idealistic. While people understand this, they may cling to it because the whole idea gives a rough orientation, or a horizon of shared values. Everybody is familiar with the idea, everybody likes the idea, but in the day-to-day routine the idea may turn out to be hardly viable. But one can still try. The community may expect that everyone is holding their rights and the obligations somehow dear, yet it cannot be certain. Reactance acts against such a common principle of shared and equal responsibilities. Someone behaving in a reactant way appears to disrupt the common rule. The reactant person does the exact opposite of what is expected of them, and of everyone else, too. Such behavior shows the opposite of what a shared belief is supposed to be for people. If anything, it shows recalcitrant or truculent actions, ignorance and disobedience.

Reactance herein disrupts a collective that bases and centers its understanding on compliance. It disrupts the collective understanding on shared responsibilities and rights. It corrupts and unsettles the shared belief of equal rights and equal duties. By disrupting the common expected behavior, reactance corrupts a common understanding of them. The common understanding appears to have an unwritten universal social code of conduct that wishes not to be undermined or violated, and wishes everyone to comply. Because, when it is violated, a whole lot of other questions arise. It is like opening up Pandora's box. Reactance appears to have the potentiality to infiltrate a collective. Therefore, it seems appropriate to incentivize the 'right' or 'good' behavior. With a little help, the 'right' behavior should appear.

Reactance could also be viewed as a lack of insight and reason. In other words, not conforming or adapting can appear as sheer ignorance and stupidity. And, to a certain degree, such a conclusion appears to be rational. You only need to contemplate the following: If it is true that the first to fall victim to acute misery is most likely to be the 
disrupter, then being adaptable seems to be the only thing that is intelligent. And, if it is true that the adapter will survive better than a disrupter in an acute crisis, then, in fact, disrupting can only be seen as a risky, you may even say 'unintelligent' and 'bad' behavior. If the issue is only choosing the right strategy in the right moment, then yes, it may seem to be primarily a matter of intelligence. The rule seems clear: Adapt!

\section{To adapt?}

A magnum glorificatio to adaptability? The psychistrist in the TV conversation may claim: 'We are very adaptable beings, and fortunately we are intelligent, too. We are capable of prioritizing new things.' Equipped with the 'good luck' of adaptability and/ or adaptiveness we simply do what is intelligent. But such 'good luck' of being adaptive is not something I, for my part, would have done under regular, or normal times. I only adapted because the situation was, and still is a crisis. I followed the guidelines, admittedly disgruntled, but I followed, knowing that these times are temporary ones and a so-called exception, not the rule, or a time of new rules. But I was equally expecting the rule, the normal, whatever that is for everyone, to come back. Therefore, I adapted during the time of exception. I was not expecting, and still do not expect, that this exception is going to be the new rule. If that were to happen, I would have rather gone with the disruption. And here, the psychiatrist and I fall apart, even though we both occupy the same space: that is, the psyche of people. I, the psychologist, would see the potentiality of reactance as a healthy reaction of resistance. This psychiatrist sees the potentiality of adapting not only as a part of healthy human reaction, but also as an intelligent (or rational) one. Both of us see the context of control. I would say, control is the necessity, or necessary space to be able to breathe, think, and act. The psychiatrist, however, would say control is the vehicle that hinders breathing as the craving for control hinders us seeing the reality of uncontrollability. She understands the desire for control as a hindrance to seeing the reality as it is, namely uncontrollable, and envisions adapting as the only way forward to come to peace with this new reality. It seems there is a new trend for adapters to come: adapting is intelligent; adaptability is intelligence.

The rationale of this psychiatrist follows the perception of uncontrollability. Fears are normal, and so are anxieties. Loss of control is a reality, just as the world we live in is uncontrollable. In the true sense of the word, we live in a world in which we have no control. This is the new reality that we should accept. Those, however, who cling to control or the feeling of control, according to the psychiatrist, will have it harder, or make it harder for themselves to be adaptive because essentially they ignore what could be called 'the new reality of uncontrollability' that the psychiatrist senses they should have come to terms with in order to survive. Only those with the intelligent capacity to adapt will survive. According to this view, I am only then intelligent if I adapt. I adapt, therefore I am intelligent. I adapt, therefore I succeed. If I don't adapt, I have not realized - that is, internalized - the 'new reality of uncontrollability.' Adaptability primarily becomes a 
matter of intelligence. Those who do not adapt, seem to show their inevitable dumbness. Those who show reactance and are disrupters primarily seem to be imbeciles, too. They just have not learned what needs to be learned now: the 'adapting to the inevitable.' Adapting is now the currency for success. Adaption is success; disruption is failure. The price of adapting is intelligence. Adaptions shows intelligence, disruption only the opposite. Everything seems to be inevitable. All seems "logical" necessity.

Such a rational approach, however, ultimately abides by a fatalistic worldview. This rational outlook seems to have an attentive eye only for success and its illusive controllability through intelligence, while turning a blind eye to another matter completely, and that is: I will succeed only if I am willing to pay a price, and that price is forfeiting the rights to my personality, my individuality, my me. Maybe here lies the answer to why I observed, with mixed feelings, yet fascinated, those who would not comply, who disrupted or became reactant. Apparently, they showed me that I, the adapter, have been missing something the whole time. I seemed to have missed what they had told me while not explicitly saying so: they feared the danger of becoming subservient in an environment of total control and personal exposure.

\section{Not to adapt!}

Reactance, on the other hand, can be seen as a form of resistance. It can be considered as a behavior that refuses to comply when you think adapting or obeying does not do you any good. You resist behaving in an expected way because you sense the demand instead of doing good harms you. That is, you resist a rule that seems to have no justification to you. Unjustified rules are means of oppression, despotism, and unjust ruling - on the small scale within families as well as on the larger scale within societies. Unjustified rules can also be means of bigotry, dogmatism, and self-righteousness. Family members as well as nation leaders can tyrannize their people, without realizing their ruling is unjust. Individuals as well as institutions can remind that certain moral values are in fact polarizing (e.g., the right to abortion versus the right of an unborn life), utilizing therefore the means of control and compliance, sometimes with the best intentions in mind. Reactance could be regarded as a defense reaction to such misuse. It is a reaction to otherwise overly adjustment to a rule that appears to have no justification for the one who is reactant. It is a reaction to a curtailing of individual freedom and liberty. The reaction tries to re-establish this particular freedom. It is a 'when, if not now'-reaction. A particular freedom that was before sensed as taken for granted is now in need of being treasured. A particular freedom that was curtailed is now revealed as a 'left-over' with no real substance. Before, there was individual freedom, now it is limited - therefore the individual needs to defend it. The individual needs to show reactance.

Reactance can also be understood as a defense mechanism that individuals activate when in crisis mode. The crisis mode is a felt loss of freedom. The defense mechanism is the internal feeling of needing to re-gain control over one's lost freedom. It is the person's 
inner sphere that needs to be protected. It is the preserving of an inner feeling of control, although the person knows that they have no real outside control. The person wants to make the uncontrollable controllable - at least internally. They want to enable themselves and allow themselves the momentum, or feeling, of control.

Reactance, eventually, can be considered as a resource for individual recovery or healing, in particular under traumatizing circumstances. It can be viewed as a source of inner strength that enables an individual to re-evaluate reality, and facilitate resourceful behavior. When things become uncontrollable, the person needs to create an inner space of controllability. An inner space in their own mind allows them to have the feeling of control over something that in reality has become uncontrollable. COVID-19 is just such a reality. It cannot be controlled by a single citizen, yet every citizen can contribute to making this reality controllable again.

When the need for adapting also translates into restricting of personal or civil rights that a person senses as important to them, then the following paradoxical advice may help them to survive such external states of restriction.

The first of two paradoxical pieces of advice is that you need to isolate yourself even further than already recommended. You seclude yourself and undergo an even further, more extensive isolation. You isolate yourself even more than demanded. You allow only a very restricted inner circle (may it be family or friends) to be part of your daily routine. In a sense, you need to show an over-adjustment. The reason why you would do so is because from here on, with that decision, you will have regained control. From here on it is your space, inner and outer, and only you decide how big or small that space should be, not anyone else. In a way, you have created an extra 'inner room' of control. So, by overadjusting you will create a space of control.

The second paradoxical advice is as follows: At the same time while over-adjusting in the one, you under-adjust in the other. That is, you do exactly what you could not do now and never could have done before. As the circumstances are 'different' they are equally uncontrollable for you. But you want to keep that control, even if it means of having control on an inner level only. That is, for example, you dress up as normally, keep your morning routine as if you were able to go out any minute (admittedly a ridiculous sentiment at that time). You cook, wash, clean as usual. You do the exact opposite of what everyone would do when having the chance to do the exceptional. You keep the routine. You do such a paradoxical thing because you want the isolation to be part of your own deliberate decision and not that of others. When the circumstances change again, it is outside your hands what you can do and what not. Yet, you still have that feeling of control even when you know that you have no control. So, in order to survive an uncontrollable situation you need to create an 'inner room' that only you control, and from which you can adapt and adjust as you see fit, and nobody else. In a sense, you need to show an underadjustment because, again, this will provide you with the necessary feeling of control that otherwise you will have lost. 
The idea is that you want to make an internal space for yourself that no one else can control but you. It is, so-to-speak, a protection room that protects you from the outside world. It is an inner space that no one else can enter. It is the source of your strength and resilience. You have no control of the overall situation, but you have gained control over this little bit - by your deliberation and imagining. By accommodating your thoughts and behavior, you create a new space, a space of personal control, which equates to a space of personal freedom. A victim leaves an oppressive experience in a somehow strengthened way when they were able to create and preserve an inner protection room with absolutely nobody else having control over it. A victim, however, leaves an oppressive experience in a somehow broken way when having no such chance to make an inner experience of seclusion, protection, and remaining in control. A victim without such a space can break; a victim with such a space can feel stronger.

If the above is true, then reactant or 'disruptant' individuals should better survive a crisis mode. Why? Because they resist in a way that allows them to envision some control over their restricted life.

\section{To adapt, or not to adapt - a question about recognizing the timeline?}

Undoubtedly, the distinct characteristic of both the acute crisis mode and chronic crisis mode is the timeline. An acute crisis will last for a visible, and recognizable time frame only. However painful it is, an acute phase will not remain for an unpredictable period of time. It will pass. We can anticipate that it will end. Eventually it will be over. Even when being in acute crisis mode, one can be somehow be certain that this particular crisis will end at some point. A chronic crisis, however, continues for a longer time, with nobody knowing how long exactly it is going to last. And such a realization can make it feel, indeed, as if it will last forever. It encompasses insecurity, and unpredictable future times. The present crisis, as it turns out, is an acute crisis. Yet, it feels (or felt) in the acute phase as if it lasts (or lasted) forever, and it is still unknown what exact future it effects.

Essentially, it appears reasonable at present moment to assume the 'long shot' instead of the short. Such an assumption or reaction, even if just a psychological one, is in fact a reasonable reaction. Not knowing what the future brings, and not knowing how long such predicaments will last, will leave the human psyche in intense and agonizing unrest - therefore it appears everything but stupid to have feelings of doubts and/or needs for disruption. Wanting to keep control while waiting could be a survival mode for the human psyche in times of uncertainty and unrest. Thus it becomes reasonable to behave as if we were living in a constant crisis, even if the crisis is supposed to be temporary.

\section{To adapt, or not to adapt - a question about rationality?}

Given that reason appears to be essential for recognizing the difference between a long-term and short-term crisis that then guides which strategy to choose, disrupters seem to have just misunderstood the crisis modes - that is, they mix up the constant, 
chronic crisis with the temporary, acute crisis. When the right strategy seems to depend on the ability to recognize a crisis as foreseeable or not, reason seems to be the key. In comparison, people who see the present crisis as ending as expected, who equip themselves with the necessary virological knowledge, and trust that society can and will counteract - such people appear sensible. Furthermore, it seems realistic, and even necessary, to assume that the present crisis is not comparable to other longer lasting crises, such as times of war or social unrest. If it is a matter of comprehending that difference, then it can be argued that disruptive behavior under the present conditions is a matter of intellectual incapacity or non-comprehension. We then account adapting and disrupting simply as matters of rationality, and reactance will be accounted primarily as irrational behavior due to the lack of recognizing the different circumstances concerning the duration of the crisis. The disrupter lacks knowledge, or they are simply unwilling to learn what should be easy to understand, namely that this present crisis will be a temporary one only. They plainly misjudge and misunderstand the present crisis, as a long-lasting one with no end at sight - only because of their lack of rationality. Yet is it that easy?

If the argument is truly about rationality (intelligence, respectively) only, then it is equally intelligent to feel uneasy about the unpredictability of the short-term and longterm future timeline. If you like to believe a decision is just easy because the duration of the crisis indicates which decision is to be made at which time, and if you also like to believe that this would primarily be a matter of intelligence, then one can have reasonable doubts with your reasoning, too. In fact, the duration of the present crisis is still unknown. We need to reasonably assume that the crisis will be temporary, but we cannot be certain about that.

Considering that reactance and disrupting behavior are viewed as wise behaviors by one, yet as simple stupidity by another, this begs the question of what holds true. The one account challenges the other, and both cannot hold true simultaneously. If both hold some credibility, however, then a nagging doubt should be a constant companion in one's own conviction. You cannot reasonably believe that disrupting (or adapting) is wise and stupid at the same time. As a result, acting and reacting at the right time, in the right way, with the right strategy, and in the right moment, reveals itself as a mirage. When the future is uncertain, there is no single right decision but a multitude of right and wrong decisions. When there is not one single right strategy, there is a multitude of right and wrong strategies; all of them potentially right, but equally potentially wrong. When the future is uncertain, nobody can specify a behavior way that is safe, or predict a consequence that is definite. Instead, everyone needs to acknowledge that there are safer behaviors than others, and that there are more likely consequences than others. Yet, there is no certainty about that. There would be certainty only after the consequences of the action. 


\section{To adapt, or not to adapt, that is the question!}

Overall, it seems puzzling that reactance and resistance are considered as uncooperative, stupid behaviors on the one hand, yet as the inner strength of the feeling of control and freedom on the other. What is the value of reactance in a real crisis then? Is it really just simple stupidity, or may it be benevolent or hardwired? Is it a necessity and a necessary resource in order to survive a crisis well, and in a mentally healthy and good way? It is the one? Or the other? It can hardly be both as the explanations are diametrically opposed. Yet, how should we properly understand reactance in crisis when we are in a crisis? It seems we cannot.

It also seems puzzling that reactance and resistance, as described here, can occur in a non-harmful way and as a resource. It is practiced in an inner, silent, not-judgmental, non-invasive, and not-demanding way. It does not demand from others that they follow, nor does it claim to know how to react in a specific context. It will not use force or become violent, not will it use cleverness to outwit or ridicule others. Reactance here is primarily a non-violent intervention to survive a crisis well.

How can we account reactance and resistance as being non-violent when the social fabric of our present times is full of societal unrest, societal injustice, and societal upheaval that calls for resistance in a more violent fashion? To a certain extent it seems we cannot account for that.

\section{To adapt and not to adapt, is that the answer?}

It can be argued that the psyche of the human mind exists not only to adapt to the deficiencies or 'inadequacy' of life. The human psyche exists, too, for the purpose of 'becoming aware' of these insufficiencies, to 'realize' and to 'remain cognizant' of the fact that it can change these insufficiencies. The evolution of humankind, and of civilization, is ultimately a matter of the capacities of a 'critical mind' and of an 'adaptable mind/ mindedness.' If, however, 'adapting' is the only thing that counts, it would mean that I need to become submissive. I need to subjugate myself. I subjugate myself, and submit to the ineluctable. I would willingly let my hands be cuffed in the 'unavoidable' - that is, the rational attitude of adapting to the unavoidable. I would need to do what would be demanded of me, and I would need to resign to the inevitable. I would need to allow myself to start being helpless. Eventually, I would stop being the person that I was. I would become subservient, a servant, a slave. I would stop existing as the person that I was. And I would need to start to acting, believing, thinking, and feeling like a robot - to react, adapt, be intelligent! With times as they are, this particular human fear alludes to another mystery of these times: the lack of the capacity to envision humanity through 
the eyes of opponents.

What could we learn from the present crisis and in particular from our behavior during the time of quarantine? I would say: we should not underestimate reactance, the behavior to not comply when you mean it does not do you good.

\section{Transforming Reason to Go with the Flow in COVID-19 (by David Kohlberg)}

My reaction to the reaction to the SARS-COV-2 virus went from humor, to irritation, to "go with the flow" peace. Observing what I thought to be an unintelligent response initially gave rise to humor. When my personal intentions and activities were thwarted, I became irritated. In shifting to make the best of it, I sought, on the one hand, understanding of deeper patterns of human social movement, beyond surface causes and reasons, whether conventional or "conspiratorial"; and, on the other, I sought to rest in the advice of "Lao Tzu", to be "like the Female" and bend and go with the flow. The Sage is tentative and fearful he says. I sought a better understanding of fear.

I have cycled between these responses, especially between irritation and "gowith-the-flow" peace, with the latter position being the one of greatest practical advantage as well as peace of mind. I have been fortunate to have places from which to conveniently be with the flow.

The call seems to be to integrate "Female" Taoist wisdom with "Male" "executive intelligence". Lao Tzu says the Female is always stronger than the Male, and these events seem to support that. How do we recalibrate "executive intelligence" when we "jump into the sea"?

When I analyze it clearly, the pandemic environment has been favorable to my core interests, which involve purposeful in situ relations with people who are not afraid, or not afraid to explore their fears. Within the United States, there has been no practical impediment to any of my fundamental goals there. Being "cut off" from Europe and Europeans has probably been an advantage, forcing me to develop my relations in and with the United States, which fits with my conscious agenda of building relations in concentric circles from a congruent base and core. We may presume that the current circumstances are leading many to do that.

From these observations, it is clear that my "resistance" to the pandemic response has only limited my ability and imagination to make the best use of it. This, of course, is a general principle that may be applied to all of life's experiences. Resistance to reality limits one's capacity to "make the best use and truth of it". However, the germ of intelligence often arises in resistance. How do we convert the immature intelligence that arises with resistance into mature intelligence that lives within the flow of reality and the "subconscious" medium that links us to it? 


\section{Letter to Colleagues Who Are Out of Face-to-Face Reach: Mutual Intelligences and the Challenges of Covid-19's Social Landscape. From Thoreau to Latour and Beyond (by Cătălin Mamali)}

A minority is powerless while it conforms to the majority; it is not even a minority then; but it is irresistible when it clogs by its whole weight.

(Thoreau 1970, 466)

How are you getting on with your idea to take into account my thoughts about the COVID-19 crisis?7. Related to this, I feel the need to share with you a few more lines inspired by a highly stimulating text written by Bruno Latour ("What Protective Measures Can You Think of So We Don't Go Back to the Pre-crisis Production Model?") ${ }^{8}$.

Here is part of a letter shared a few weeks ago with some colleagues.

The concept and required practice of social distancing, as well as that of voluntary self-isolation during this terrible COVID-19 epidemic, which has tragic consequences and yet simultaneously reinforces the feelings of togetherness, might induce many of us to Henry David Thoreau's ideas and practice. Thoreau had in mind and practiced moral distancing from evil acts, rules, institutions.

A long time ago, Thoreau had the idea of carrying out a solitary self-experiment in order to test some basic assumptions about life's necessities and the way of living: "Walden". Of course, his self-experiment and self-isolation were not perfect. But they have been much more significant than many experiments carried out in the best social and psychological laboratories and which were not methodologically perfect either. Thoreau's epistemic, moral and social audacity have been strongly criticized, especially due to the fact that Thoreau's design aimed to explore the fundamental aspects of social life and of our interaction with nature by resorting to social isolation. This criticism of Thoreau's "isolationism" did not take into account the fact that the self-imposed solitude was conceived as a temporary and experiential state. Let us recall that resorting to selfisolation (the retreat) has a very long history, and it has been practiced in many resilient

7 This text has been conceived as a letter. I am grateful to Anne Nelly Perret-Clermont for suggesting a Latour's article to me and for her own insights on COVID-19. The main part of the present text (98\%) and its structure are identical with the text of the later shared with colleagues that I could not see face to face. A few of them are living in the same small and picturesque city I am living (Dubuque, on Mississippi, Iowa). The letter did not have this title. However, the issue of the mutual intelligence discussed by Thoreau in 1853 is present in the standard letter. I am using the plural due to the influence of the landmark conception on multiple intelligences developed by Howard Gardner under the assumption the increased number of interactive minds might increase the chances of works carried out by mutual intelligences. This letter has been preceded by another one sent in March about the terrible concept, turned many times into horrific practices, of social distancing.

8 I express my gratitude to Anne-Nelly Clermont Perret for suggesting to me and sharing with me this text when my access to Internet has been drastically restricted, and for her generous participation in our epistolary dialogue during this time that imposes, for good, and (sometimes) wrong reasons, isolation. Her insights are in consonance with the powerful theory of socialcognitive conflict. 
cultures.

Recently, Bruno Latour, the outstanding researcher who uses a transdisciplinary and integrative perspective that has excellent theoretical and practical outcomes, wrote a powerful essay: "What Protective Measures Can You Think of So We Don't Go Back to the Pre-crisis Production Model?" (Latour 2020). Latour states that COVID-19 forced billions of people to retreat, for a while, from their productive or paid activities: "The first lesson the coronavirus has taught us is also the most astounding: we have actually proven that it is possible, in a few weeks, to put an economic system on hold everywhere in the world and at the same time, a system that we were told it was impossible to slow down or redirect" (cf.). Volens nolens under the deadly threat of COVID-19 most of humankind had been forced into self-isolation, and not just into a slowdown of previous productive activities and ways of life, but into a structural change. This structural change regards what one does: how (with what means), with whom, why (what are the motives that sustain and direct our activities) and where one does what one does. In Thoreauvian language this means that the costs of human activities (work and leisure among others) must be regarded from the perspective of life time and life meaning.

Latour points out that most of us (individuals, small and big communities) are living through the process of having an insight: "Hence the incredible discovery: already in the world economic system there was, hidden from us all, a bright red alarm button with a nice big stainless-steel handle that the heads of state could pull, one after the other, to instantly stop the 'train of progress' with all the brakes squealing. If in January the demand to make a 90 degree turn to land on the Earth seemed like a gentle illusion, now it becomes much more realistic". So, Latour observes that most of us are on the point of grasping, in the hard way, what we can call "Thoreauvian insight": in order to better understand the good functioning of society, of human relationships, of lifestyles, and of our inescapable relation with Nature, it is useful to conduct a solitary experimentation, a well-conceived social isolation and separation from the dominant habits.

Nonetheless, there are some features of the Thoreauvian social self-experiment that are missing in the present crisis. I refer to the following:

1) Thoreau had the possibility to choose the time, and the place. It was a deeply individual decision. Today's "social distancing" has been imposed on us by a pathogen, by its global power, and by a globalitarian power (authoritarian-like style at global level). The notion of "globalitarian", which may sound strange, attempts to capture the tendency of abusing the long-term historical process of globalization in an authoritarian way, as totalitarian social systems did and do. The world is more and more interconnected. However, this does not mean that one single way, style or mode of becoming should be dictatorially imposed on every social group, nation and society;

2) Thoreauvian self-isolation was deeply active and creative. It seems that many of those who must practice self-isolation today are pushed into a passive mode. Of course, 
there are still those who work at home, and those who are courageous and much-needed front line actors (basic services, medical personnel, first responders, etc.);

3) The Thoreauvian experiment was pro-active, while the present response to the pandemic is re-active;

4) The Thoreauvian practical inquiry aimed towards, and was mostly carried out in, a self-reliant mode ${ }^{9}$, while many (how many?) of those in self-isolation, nowadays, are in a state of dependency;

5) Thoreau watched carefully the satisfaction threshold of his basic needs in order to seize the opportunities for self-transcendence.

I assume that the threshold for satisfying basic needs and escalating them artificially might rise during and right after this crisis. I deeply hope that this assumption will be refuted, despite the fact that it seems to be have a predictive value. Nevertheless, if this will happen then it will block individuals and communities from reaching co-developmental motivational patterns and from self-transcending needs.

Latour, who by the way explored the essential features of Pasteur's experimental work $^{10}$, warns us about the power of the "germs" that are supposed to bring rapid transformations: "Germs are super-globalisers: when it is a matter of resocialising billions of people, the germs make short work of it!" (Latour 202011).

There is no doubt that life-and death circumstances generated by natural forces, some invisible as germs, might induce speedy changes. In opposition to changes produced under the threat of external forces, Thoreau searched for inner changes, based on high moral principles that are existentially conceived and accepted by the individual.

Latour offers readers a great chance to think about their behavior in a proactive mode and to prepare themselves for a needed change. He poses a few questions, as part of an engaging exercise. Here are the first two:

Question 1: "What are some suspended activities that you would like to see not coming back?"

Question 2: "Describe why this activity seems to you to be noxious/superfluous/ dangerous/ incoherent, and how its disappearance/putting on hold/substitution might render other activities that you prefer easier/more coherent" (Latour 2020).

As a social psychologist who lived for 45 years in a country repressed by a

9 Regarding the features of Thoreau's social philosophy, his political views and moral choices there is a huge literature from which I am reminding just a few landmark contributions (Gougeon 1990, 1995, 2005; Harding 1970; Harding \& Meyer 1980; Kateb 1983, 1992).

10 Latour explored the essential features of Pasteur's scientific practice and the conditions that can enhance its social generativity and, with his colleague Woolgar, suggest that the scientific facts are themselves submitted to the social construction processes (Latour 1989; Latour \& Woolgar 1986).

11 Latour's ideas, which are in tune with anthropological studies of scientific laboratories (KnorrCetina) ask explicitly for a rational, scientific perspective on the scientific activity itself and of its social consequences (see Knorr-Cetina 1981, 1999). 
totalitarian system, and as one who had the chance to get to know many of Thoreau's works, I have been puzzled and I am still puzzled, by the reluctance of some major socialpsychologists and social scientists to enrich their own approaches based on Thoreau's crucial contributions to a series of vital issues such as:

1) Civil disobedience - for separation from evil structures, laws and practices;

2) An unobtrusive, non-violent, friendly relationship between the experimenter (knower) and the object (the subjects, which most psychologists today refer to as "participants", while the experts are still manipulating them). Thoreau was explicitly against violent research methods. On the soft side of the spectrum many social scientists resort to manipulation (cover stories, lies - useful for testing hypotheses) and still call the individuals involved in the research "participants" - this is to say a participant in his/her own manipulation by others! I addressed this issue in a work called "Interknowledge"12. On the extremely hard side of violence used in some scientific studies we have tragic cases such as those explored by Katz (1984);

3) Thoreau's way of grasping the question of minorities, a long time before social psychologists approached it, and that of the "majority of one"13;

4) The ecological perspective ${ }^{14}$ developed and practiced by Thoreau;

5) The practice of self-experimentation, and his unobtrusive epistemic orientation. His ideas and practice are much richer.

I noticed a systemic resistance to Thoreau's ideas on civil disobedience in Romania not just before 1989 (the collapse of the communist regimes in Europe) but a long time after 1989. Despite many proposals (including the free copyright offered for the first time by Walter Harding) the main publishing houses (Humanitas and Polirom) did not publish Civil Disobedience or other political studies (Reform papers). There is a fear at the individual level, which might also have systemic roots, of recognizing and integrating some of Thoreau's crucial ideas, as is the case with his conception of "minorities". The issue is more complex due to the fact that some major social psychologists (H. Tajfel, J. Turner, S. Moscovici, M. Billig, G. Mugny, for instance) who made landmark contributions in this area did neglect or have been reluctant to discuss Thoreau's groundbreaking ideas. Their theories on minorities, identity, social-categorizations are crucial contributions for social psychology and beyond its formal borders and rhetorical ways. At the same

12 The use of violent means (cover stories, lies, insulting words, etc.) in some landmark experiments might have a long term negative social learning effect on former subjects: they learn that one could use violent means in order to reach the truth (Mamali 1974, 2011).

13 Thoreau views on the smallest limit of minority that is referred as "the majority of one," that acts based on high moral principles against unjust laws, behaviors and institutions" was presented by C. Mamali (2011).

14 Thoreau's inspiring conception on human relation with nature as well as his creative and friendly research practice are approached by Buell in his comprehensive and illuminating work on environmental imagination (Buell 1995). 
time, it is amazing how Thoreau's powerful ideas and social practice regarding the social condition of minorities have been neglected so long by leading scholars on minorities ${ }^{15}$.

Thoreau's conception of minorities is deeply connected with his epistemic and moral care for the "silent majority". Marx also was concerned by the fate of the oppressed majority. However, while Thoreau trusted the responsibility and thinking powers of each and every individual, and was against relegating these inner powers to external authorities, Marx pleaded for the leading role of the political vanguard of the masses, which he called the Communist Party. In conflict with Thoreau, who stimulated the inner decision power of each individual, Marx's conception prescribed a political algorithm for social change that was considered by him and Engels to be universally valid (The Manifesto of the Communist Party). Unfortunately, this political algorithm has been applied with tragic consequences.

In contrast, Thoreau's heuristic and method of civil disobedience nurtured nonviolent changes. Thoreau's ideas are highly significant for a special type of minorities: the autochthone minorities, who in some cases, initially, were a majority in relation to newcomers, but their relative demographic size decreased over time (there are many cases across the world: North American Indians, Armenians, native South Americans and Australian populations, and so on). We may ask a hard question: how are going to look at such minorities after the COVID-19 crisis, when this virus and our ways of reacting to it will be a thing of the past?

When the logic of a critical situation and a painful social problem stimulate the researcher to resort to a Thoreauvian conception and experience in a creative mode, as is the case with Latour's essay, promising perspectives might arise.

Let us hope that the good use of human imagination, also the great inter-human resource recognized by Thoreau in his Journal (January 1853) and called "mutual intelligence", is more powerful than a virus, even one called Covid-19. Mutual intelligences

15 Among some of the landmark studies that deal with the issue soft minorities, in-group, outgroup, social-categorization and social identity that explore essential aspects of the relationships between minorities and majorities, which, unfortunately, neglected Thoreau's contribution to this question there are the following works (Billig \& Tajfel 1973, 27-51; Moscovici 2001; Moscovici \& Faucheux 1972, 149-202; Tajfel 1978; Turner et al. 1987). To make it clear: all of these works are outstanding works that advanced in a critical way the field of social psychology. However, for reasons that might deserve a special study, all of them neglected Thoreau's innovative conception on minorities and Thoreau's own experience and method of civil disobedience. I tried since many years to bring to awareness this issue a few times to some of authors mentioned above.

Fortunately, I received an answer from Michael Billig on May $13^{\text {th }} 2020$ on this issue mentioned in my letter. I am grateful to Michael Billig who offered his answer to this puzzle expressed in my explicit question: why Thoreau's ideas on minorities have been neglected? Billig wrote: "And many thanks for your thoughts on Thoreau and the relevance of his ideas today. You are correct in saying that I have not made use of his ideas. The reason is quite simple. It's not that I find them unsatisfactory in any way: worse than that, I have never read Thoreau. I can only justify my ignorance in terms of cultural bias. Thoreau is not a fashionable author in Britain - very few people read or discuss his works."

During time I had the privilege to meet Michael Billig face-to-face a few times and to learn from him and from reading many of his fascinating works as are, for instance, his original contributions to rhetorical psychology and to political psychology. His answer gives me hope that Thoreau's conception on minorities and other relevant issues will reach more creative social psychologists. 
might help to overcome the inertia of powerful misconceptions and bad social habits. I use the plural (mutual intelligences) in consonance with Gardner's landmark theory of multiple intelligences ${ }^{16}$ that are expressed by different individuals. At the same time, the idea of "mutual intelligence(s)" suggests that each individual's form of intelligence has a greater potential if it is involved in a mutual relation with other intelligences.

Please find a few thoughts triggered by the "VIRAL" use of the syntagm "practice social distancing" that I shared in the last months with a few colleagues and friends.

\section{On social distancing}

It is at least strange how quickly and widely the syntagm has spread that aims to be laconic advice during this time: "the practice of social distancing." I do not know what the reaction to this issue is in your city, with a relatively high demographic density, and if this expression is used as much as it is here in the Midwest. One great exception is Boris Johnson, not from Midwest, who talked loudly and clearly about the necessity of PHYSICAL distancing, while a scientist (at least a person with scientific education) who turned into a politician (as Ms. Angela Merkel) keeps saying "social distancing" - quite a bizarre linguistic preference for a politician who claims to be a champion of immigration without borders and restrictions.

It seems that a troubling symptom is emerging in many countries: the multiplication of the ideas and intentions (sometimes even small-scale experiments) to expand political control in the bio-medical and bio-social realms. The Authoritarian Faucet (for the distribution of goods, information, evils) imagined by Gandhi much earlier than Orwell and others seems to include bio-markers (of health/illness) far beyond the necessary area of therapy, of medical treatment. I hope to be wrong. Despite this hope, I know for sure that besides the tragic loss of many lives there are also many collateral victims of the societal ways of reacting to COVID-19. Obviously related to the misleading concept of "social distancing" and to the unequal access to Internet there are the communication troubles. During COVID-19 the number of collateral communicational victims has increased. Communication is a form of emotional, intellectual, and social breathing. Social distancing hinders this form of cultural breathing and feeds alienation. Why is COVID-19 used and abused for nasty political games? Also the coming army of "contact tracers" poses serious moral questions because its abuses might outweigh its benefits.

We learned from Freud that speech errors (the Freudian slip) are important indicators of possible hidden political intentions. In his work on repression, which is explored in an outstanding way by Billig ${ }^{17}$, Freud was inspired by political censorship practices (including cuts in the newspapers) that reached Vienna from the Tsarist Russian

16 Among Gardner's works that present his landmark theory of multiple intelligences and its ramifications I remind only the following few (Gardner 1993, 1995, 2004).

17 Billig (1999) develops his innovative approach on repression and its presence within social encounters and conversation. 
Empire. During this period, some of the mainstream radio stations (NPR, IPR, APM) provide examples of Freudian slips that are not followed, most of the time, by apologies. Just one example from a long series: On May $8^{\text {th }} 2020$, during morning edition (at 7:10 AM) at IPR, the host - Clay Masters - said a few things about problems with food supplies by "groceries, farmers...." in Des Moines, Iowa.

At one point, Clay Masters said "flu supply" instead of "food supply". Quite an error: the "flu (Covid-19 in the sub-text) is supplied." Without any excuses (this is rather a general procedure of NPR with errors such as Freudian slips) he quickly said "food supply". Is it just a joke made by some moguls of the mainstream media behind the scene? Anyway, based on Freud's concept of repression, it seems that this involuntary joke produced by a mainstream media person, not by a common listener, tells us more about how COVID-19 is represented. It is hard to know now if this error has been influenced by the ways some moguls of the mainstream media talk behind the scenes about the present crisis or by other factors.

Is more trust or distrust going to dominate the post-COVID-19 era? What is the balance between trust and mistrust from micro levels to macro-levels going to be like?

Be well and safe,

Catalin

\section{References}

Askland A. 1993. "Charles Taylor Against the Negative Sense of Freedom: An Unjustified Collapse and a Persisting External Authority," Auslegung: A Journal of Philosophy 19(2):123-132. DOI: https://doi.org/10.17161/AJP.1808.9382 (last accessed on August 21, 2020).

Billig M. 1999. Freudian Repression. Conversation Creating the Unconscious. Cambridge: Cambridge University Press.

Billig M. \& Tajfel H. 1973. "Social Categorization and Similarity in Intergroup," European Journal of Social Psychology 3:27-51.

Böhme J. (1977; Orig. 1612). Aurora oder Morgenröte im Aufgang. Freiburg/Br.: Holzinger.

Buell L. 1995. The Environmental Imagination. Thoreau, Nature Writing, and the Formation of American Culture. Cambridge, MA: The Belknap Press of Harvard University Press.

Fromm E. 2013. Escape from Freedom. New York: Open Road Integrated Media.

Gardner H. 1993. Creating Minds: An Anatomy of Creativity Seen Through the Lives of Freud, Einstein, Stravinsky, Eliot, Graham, Gandhi. New York: Basic Books.

Gardner H. 1995. Leading Minds. New York: Basic Books. 
Gardner H. 2004. Changing Minds: The Art and Science of Changing Our Own and Other People's Minds. Boston, Mass.: Harvard Business School Press.

Good G. 1988. The Observing Self. Rediscovering the Essay. New York: Routledge.

Gougeon L. 1990. Virtue's Hero: Emerson Antislavery, and Reform. Athens: University of Georgia Press.

Gougeon L. 1995. "Thoreau and Reform," in J. Myerson (Ed.), The Cambridge Companion to Henry David Thoreau. Cambridge: Cambridge University Press.

Harding W. 1970. The Days of Henry David Thoreau: New York: Knopf.

Harding W. \& Meyer M. 1980. The New Thoreau Handbook. New York: New York University Press.

Kateb G. 1983. Hannah Arendt. Politics, Conscience, Evil. New Jersey: Rowman \& Allanheld.

Kateb G. 1992. The Inner Ocean. Individualism and Democratic Culture. Ithaca - London: Cornell University Press.

Katz J. 1984. The Silent World of Dictator and Patient. New York: Free Press.

Knorr-Cetina K. 1981. The Manufacture of Knowledge. Oxford: Pergamon Press.

Knorr-Cetina K. 1999. Epistemic Cultures. How the Sciences Make Knowledge. Cambridge, Mass.: Harvard University Press.

Latour B. 2020. “What Protective Measures Can You Think of So We Don't Go Back to the Pre-crisis Production Model?" Trans. by S. Muecke. URL: http://www.bruno-latour. $\mathrm{fr} /$ sites/default/files/P-202-AOC-ENGLISH.pdf

Latour B. 1989. The Pasteurization of France. Cambridge: Harvard University Press.

Latour B. \& Woolgar S. 1986. Laboratory of Life: The Social Construction of Scientific Facts. Second ed. Princeton: Princeton University Press.

Leontyev D. 1996. "From Social to Personal Values: Sociogenesis and Phenomenology of Value Regulation of Activity," Bulletin of the Moscow University 14(4):35-44.

Mamali C. 2011. "Majority of One. Political Manifestoes and the Quality of Social Movements" at an interdisciplinary international conference Theory, Action and the Impact of Social Protest, University of Kent, UK, October 13-14.

Mamali C. 1974. Intercunoaştere [Engl. Interknowledge]. Bucureşti: Editura Stiinţifică.

Mamali C. 2011. Ideologically Motivated Self-deceit, the Self-hatred and Hatred of Other: Freudian Repression in Communism and Post-communism (Orig. "Auto-amăgirea motivată ideologic, ura de sine şi ura față de ceilalţi: represia freudiană în communism şi post-comunism,") in J. Barus-Michel \& A. Neculau (Eds.), Psihologia crizei. București: Editura Trei.

Moscovici S. 2001. Social Representations. Explorations in Social Psychology. Ed. by G. Duveen. New York: New York University Press.

Moscovici S. \& Faucheux C. 1972. "Social Influence, Conformity Bias, and the Study of Active Minorities," in L. Berkowitz (Ed.), Advances in Experimental Social Psychology (pp. 149-202). New York: Academic Press.

Sokolova E. T. 2014. "The Loss of Self: A Clinical Phenomenon or a New Cultural Norm?" Epistemology and Philosophy of Science 3(40):191-209.

Tajfel H. (Ed.) 1978. Differentiation between Social Groups: Studies in the Social Psychology of Intergroup Relations. London: Academic Press. 
Taleb N. 2007. The Black Swan. The Impact of the Highly Improbable. Random House Trade Paperbacks (e-pub).

Thoreau H. D. 2005. Walden. San Diego: ICON Classics.

Thoreau H. D. 1997. Journal, Vol. 5, 1852-1853. R. Sattelmeyer (General Editor) \& P. F. O'Connell (Ed.). Princeton: Princeton University Press.

Thoreau H. D. 1973. The Reform Papers. Ed. by W. Glick. Princeton: Princeton University Press.

Thoreau H. D. 1970. The Annotated Walden. Walden; or Life in the Forest by Henry D. Thoreau Together with "Civil Disobedience". A Detailed Chronology and Various Pieces About Its Author the Writing and Publishing of the Book. Edited, with an introduction, notes and bibliography by P. Van Doren Stern. New York: Clarkson N. Potter, Inc.

Turner J. C., Hogg M. A., Oakes P. J., Reicher S. D., \& Wetherell M. 1987. Rediscovering the Social Group: A Self-Categorization Theory. Oxford: Blackwell.

Yalom I. D. 1980 (Orig. 1931). Existential Psychoterapy. New York: Basic Books. 
Bruce B. Janz (Orlando), Eka Kaznina (Sankt Petersburg), Kim Jihyun (Seoul), Claudia Ammann (Dunedin, Otago), David Kohlberg (Bodghaya, Bihar), Cătălin Mamali (Iowa)

\title{
COVID-19 Forced Social Distancing and Isolation: A Multi-Perspective Experience
}

\begin{abstract}
The article is combined of six chapters authored by these who voiced their experiences with social distancing during the COVID-19 pandemics in various contexts, but mostly centered on psychological, sociological, and ethical aspects. Authors, mostly psychologists and philosophers, were invited to describe their perspectives on the sense and practice of social distancing in times of pandemics. Their reflections seek to demonstrate various perspectives related to subjects' novel self-experience, social situatedness, and their dealing with conventions and habits altered through the pandemics. As "the owl of Minerva takes its flight only when the shades of night are gathering" (Hegel), there is no conclusion in this article. It rather encourages other authors to reflect on the nearly global, still lasting phenomenon.
\end{abstract}

Keywords: social distancing; isolation; COVID-19; pandemics; self-experience; relatedness to the world; socio-moral relations; multi-perspectivism; the Theory of Black Swans; Böhme; Good; Lao Tzu; Popper; Sokolova; Taleb; Thoreau

Ethics in Progress (ISSN 2084-9257). Vol. 11 (2020). No. 1, Art. \#2, pp. 20-60.

Creative Commons BY-SA 4.0

DOI:10.14746/eip.2020.1.2 